\title{
馬匹傳染性貧血症診斷法卜ンテノおつぺる ま人氏家兔接種試驗二就テ
}

\author{
農林省獸设調查所 \\ 中村哲哉松葉重 雄 \\ 川村泰宮川文雄

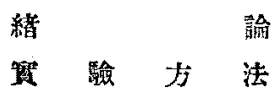

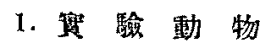 \\ 2. 接種材料 \\ 3. 检 查方 法 \\ (1) 探 血 法 (5) 血液價, 算定 \\ (2) 接䅜办法及其の部位 (6) 體 溫，測定 \\ (3) 血球, 检查法 (7) 血液像 ，检查法 \\ （4）血色索檢查法(8) 脾藏剔出法
}

琵 驗 成 績

1. 等敠满馬血波接種家鬼所見

2. 對照馬血液接種家宫所見

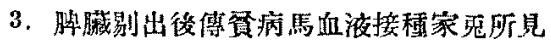

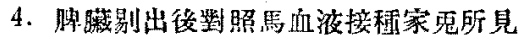

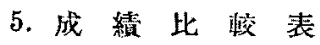

總

括

1. 一般狀態〉緗化

5. 血色素量 つ 化

2. 體溫, 微化

6. 侐液僄, 戀化

3. 赤血球數八 紸化

7. 成續, 制定

4. 白血球整, 化

粘 論
(文

緒論

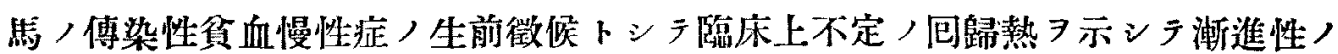

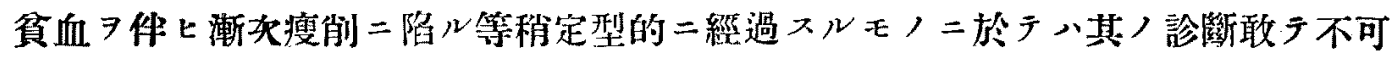
能ナルニ非ザルバキモ圣然不定ノ經過

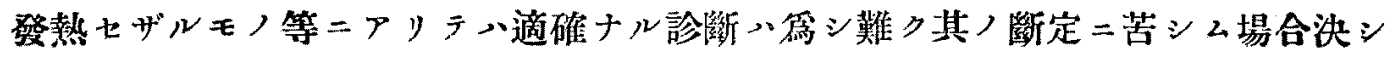
テ少シトセズ。第二之が診斷法，簡明精確ヨ期セントシテ砸究二腐心セル學者爻 


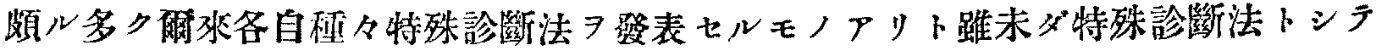
㮣用セラル、ノ域二達セルモノナシト云フモ過言ナラザルベシ。

明治 44 年本邦駡疫調查委員會二於ケル砰究業蹟中動物試驗ノ結果トシテ馬ノ 外豚八傳貧病毒二感受性

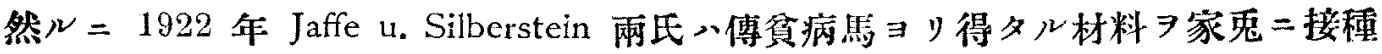

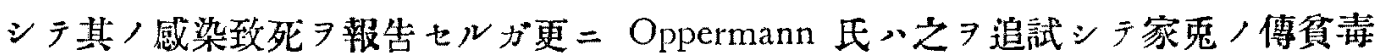
二對スル威受性 $\ni$ 碓メ其ノ發病二際シ體溫ノ上昇, 赤血球ノ減少, 白血球ノ增加 卜共二著明ナル血液價，上昇 $\exists$ 桃シ又肝及脾等二特殊變彇，實在 $习$ 認メ更二發病

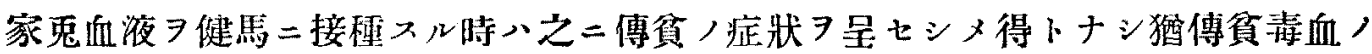

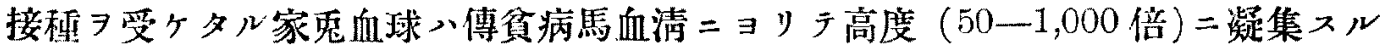

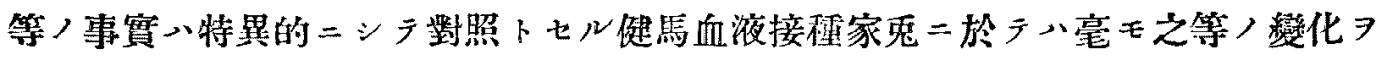
認メズトナシ以ラ家鬼入傳貧診斷上唯一ノ試噞動物ナリトセり，即キ如上示ス處

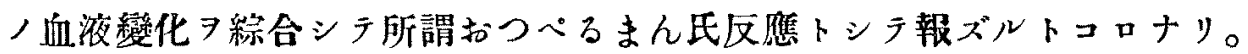

同年 Standfus 氏 34 頭ノ家鬼二傅貧病馬血液各 8.0 c.c. 宛接種シタル二内 31 頭入平圴 1 度ノ發熱 7 來シ著明ナル赤血球ノ減少 $(1,000,000-3,000,000) \Rightarrow$ 來シ此八貧血》3-6 日間速續セり反之血球ハ上昇シ血液價》赤血球減少二反 比例シラ著明ノ上昇曲線 賛同セり。其後之ガ實驗二從事スル者頗ル多キヨ加一铂ツテ種々，赫告二接スル トコロアリ,郎チHelm氏ハ30頭ノ家鬼二就テ賽驗セル結果お氏說二近キ成綪尹

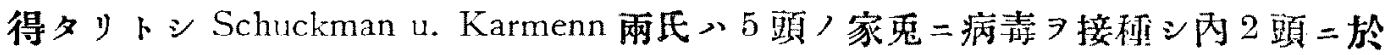

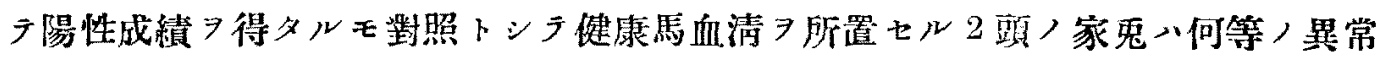
ヨ呈セザルニヨリ之ヨ以ラ全ク傳貧特異性ナリトシ F. Forgel 氏亦 8 頭八家鬼二

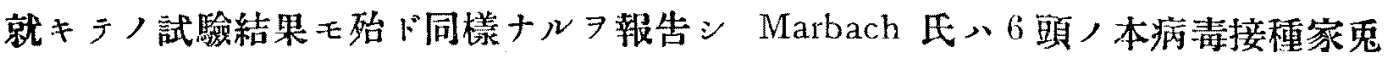
二於う體溫〉上昇入認メ得ザリシモ赤血球及ビ血液價〉曲線ハ特異ニシラお氏 成績ニ全ク一致セルヨ述ブ。Ziegler u. Grosse 雨氏》生後 6 ケ月以上

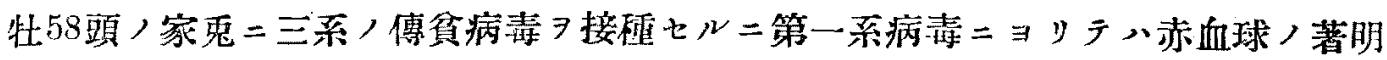

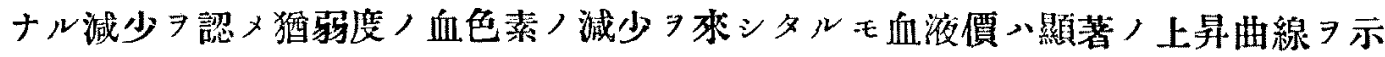
セり第二系モ殆ド同樣ノ成績 脾及肝二著明ナル變化习認メタリ第三系ハ所謂傳貧疑似馬血液ニショ之ガ接種 受ケタルモノモ第二系ト殆ド同榡ノ成辕 $コ$ 示セり而シラ感染家鬼材料ニッキ健康 
家鬼二溸头連續接種シタル結果》第 3 代迄感染七シメ得タルニ反シ對照トセル8 頭ノ家兔一何等異常 7 呈七ズ郎病毒接㮔家兔

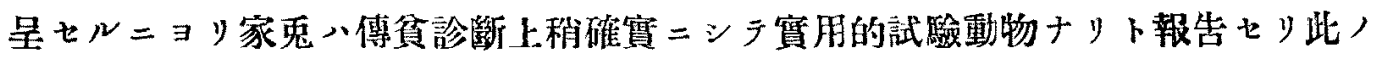
他 Schütz, Schneider, Pcters 等ノ試驗成綪モ略同樣ナル Lührs 氏入家鬼二傳貧病馬血液 接棰家鬼血液 家兔二於ラ赫血球ノ減少 7 認ムルモ著明ナル血腹價ノ曲線 Pallaspe, Sehermer, Schermer u. Eigendorf 諸氏/試驗成綪ニアリラ八健馬血液及 傳貝馬血液ノ家鬼接種共二全ク認ムべキ異常 ヨ呈セズトナセリ殊ニSchermer .u.

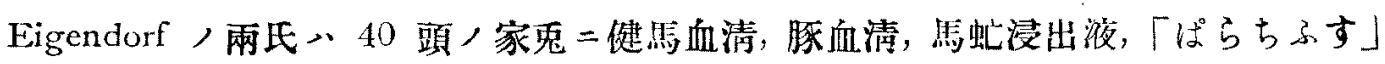

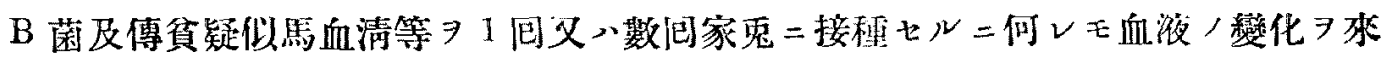
シ所謂お氐反應陽性、見做メべき絬果ヨ示セり。殊二䀠血清接種家鬼二於亏該反

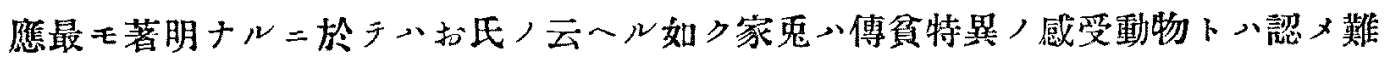

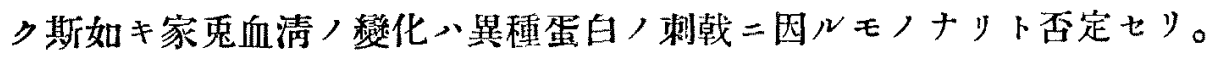

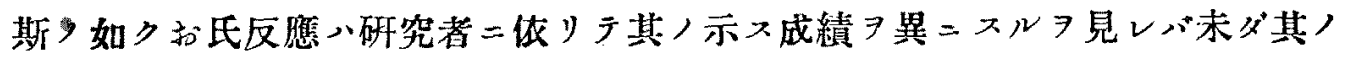
實際的價值

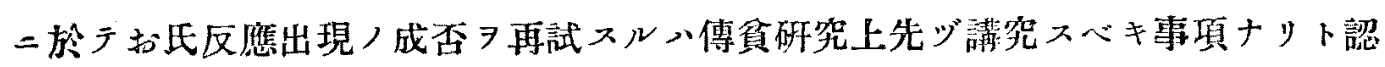

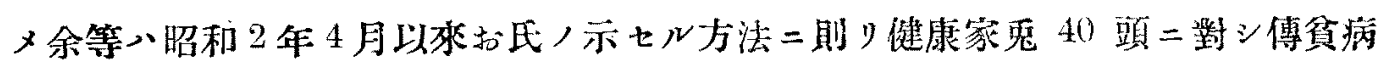

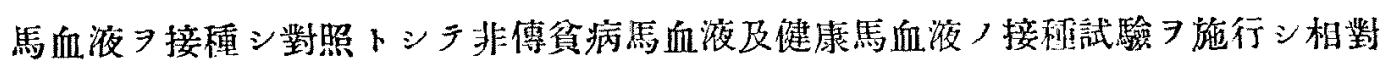
比シテ得タル成績 $尹$ 此處ニ報告セントスルモノナり。

\section{實 驗 方 法}

\section{1. 實 驗 動 物}

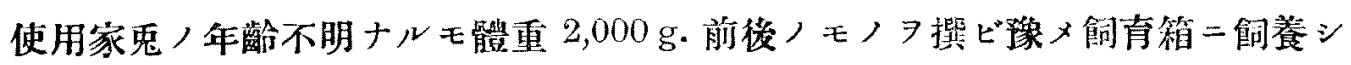
ラ健康 ヨ行ヒ血液成分二著シキ變動 ミヨ試驗二供セり。

2. 接 程 材 料

（1）傳貧病馬血液 尊告站臨床上定型的經過 7 示七儿左，10頭，傳負病 馬血液 使用材料ト七り。 


\begin{tabular}{|c|c|c|c|c|}
\hline 馬 & 名 & 所有者 & 主装 症 狀 及 經 歷 & $\begin{array}{l}\text { 接種家 } \\
\text { 番號 }\end{array}$ \\
\hline 友 & 桑 & 陸軍獸醫學校 & 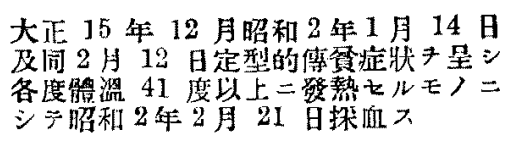 & 1 \\
\hline 遠 & 野 & 烣軍獸稫學校 & 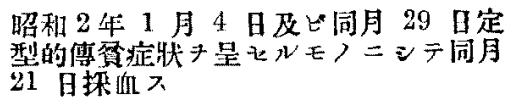 & 2 \\
\hline 遠 & 幸 & 陸軍獸監學校 & 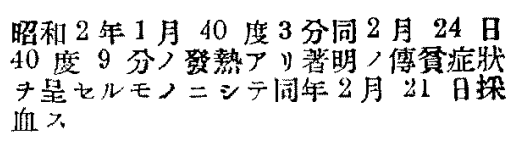 & 3 \\
\hline 高 & 田 & 青森憬高田村 & 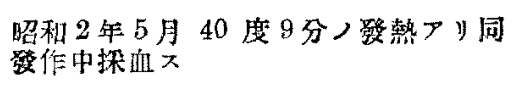 & 4,30 \\
\hline 福 & 墨 & 奥狗種熙牧場 & 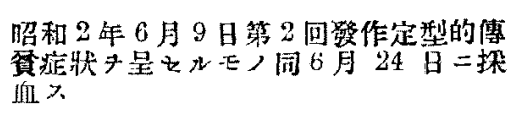 & $\frac{5,13,14}{31}$ \\
\hline 武 & 安 & 奥㭁程馬牧溃 & 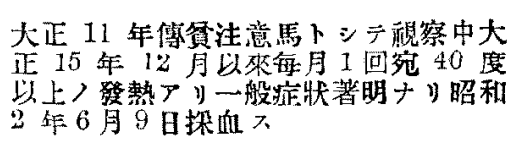 & 6 \\
\hline$t$ & F & 奥狗種熙牧場 & 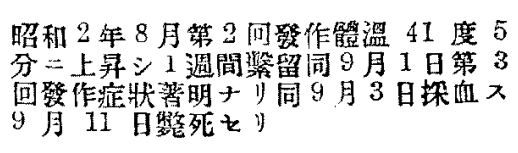 & 7,8 \\
\hline 東 & 熟 & 青森縣東獄村 & 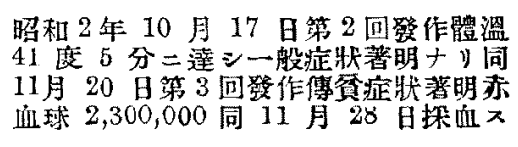 & 9,10 \\
\hline \multicolumn{2}{|c|}{ さんばれ } & 青森種駡的 & 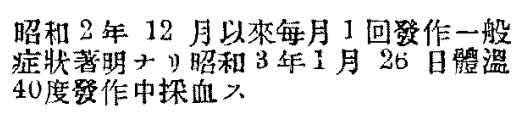 & 32,34 \\
\hline \multicolumn{2}{|c|}{ 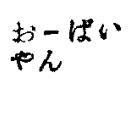 } & 青森種馬所 & 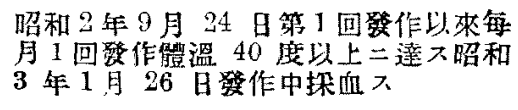 & 33 \\
\hline 南 & 極 & 靑森種馬所 & 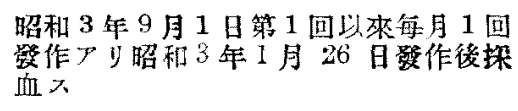 & 11,12 \\
\hline
\end{tabular}

（2）非傳貧病馬血液 下３䫒八腺疼病馬血液 7 用ヒタリ。

\begin{tabular}{|c|c|c|c|c|}
\hline 馬 & 名 & 所有者 & 声要 症 狀 及 其 經 歴 & $\begin{array}{l}\text { 接種家 } \\
\text { 鬼號 }\end{array}$ \\
\hline 輕 & 海 & 青程秏所 & 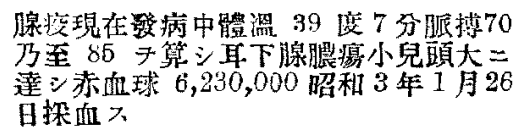 & 15,16 \\
\hline
\end{tabular}




\begin{tabular}{|c|c|c|c|c|}
\hline 公 & 照 & 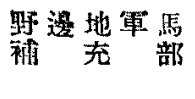 & 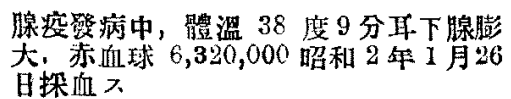 & $18,19,35$ \\
\hline 璄 & 駒 & 陸軍獸㗨學校 & 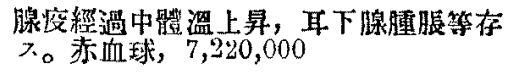 & 17,36 \\
\hline
\end{tabular}

（3）健康馬血液 當所二於于健康照血清探取用トシテ飼養中，下記 4 頭， 血液ヨ用ヒタリ。

\begin{tabular}{|c|c|c|c|c|}
\hline 馬 & 名 & 所有 诸 & 全 姴 經 歷 & 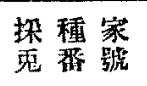 \\
\hline 第 17 & 號 & 獸没調查所 & 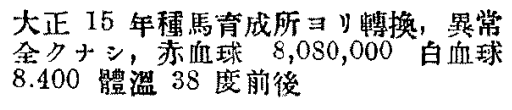 & 38 \\
\hline 策 11 & 號 & 獸资調查所 & $\begin{array}{l}\text { 大正 } 13 \text { 年 } 11 \text { 月 } 26 \text { 日昌所以來暴常 } \\
\text { 器メザルモノ赤血球 } 7,280,000 \text { 血 } \\
\text { 球 } 9.200\end{array}$ & 20 \\
\hline 第 20 & 號 & 獸洗調查所 & 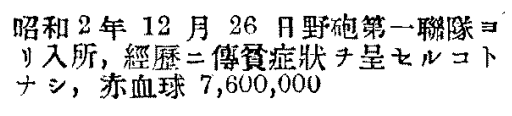 & 21,39 \\
\hline 第 18 & 號 & 獸疫調查所 & 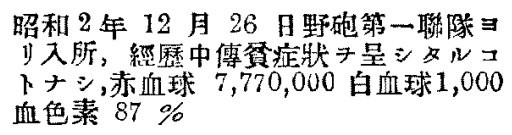 & $\begin{array}{l}22,23,24, \\
37\end{array}$ \\
\hline
\end{tabular}

3. 檢 查方 法

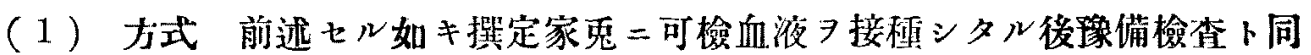
㧼ノ方法 $\exists$ 以 3 週問本檢查 $\exists$ 行ヒ依ッテ得タル成績卜豫備检查二於テ得タル 成績トヨ比較シ以ラ反應 $习$ 制定セリ。

（2）探血 每朝 9 時乃至 10 時ノ一定時刻ニ於テ「あるこはる」消毒

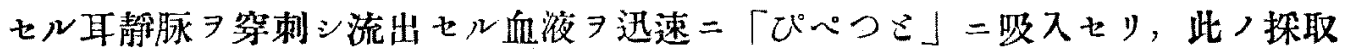
法へ一定順序師千白血球，赤血球，血色素ノ檢定及塗抹標本ノ順ニナシタリ。

（3）接種方法及其部位 接種部位八耳静脉內，皮下又八腹腔内二泩入セり 接種包數》1司ニシラ 5.0 乃至 10.0 c.c. $\exists$ 接種量トセり。

（4）血球／檢查 赤血球及白血球ノ檢查ニハを一ま, つおいす氏計算器 用七，赤血球＼cjkstart稀釋二八0.85\%生理的食監水，白血球二八つゆるく氏液 又赫血球、200 倍白血球》20 倍二㮁翠ショク振蕰本等二混和セシメタル上先 ッ゙5-6 滴ヨ捨テタル後計算室二收メテ檢查セり。 
（5）血色素，喻查 二八ふらいし，み一しえる氏血色素計 7 用七 $0.3 \%$ 炭

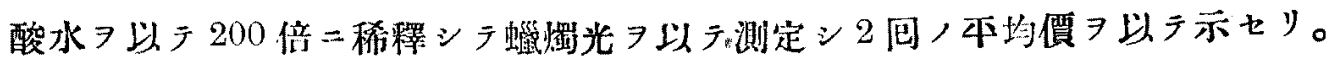

(6) 血液價，算定 接種前後二於于血色素量 7 各赤血球数 7 以于除シタル 商ノ比ニシテ方式 9 以示セバ次ノ如シ。

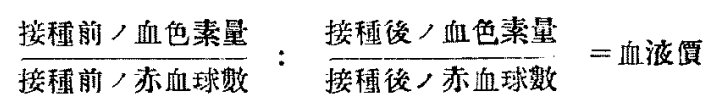

（7）體溫每日探血時 7 定メ午前 9 時乃至 10 時ノ間二測定セり。

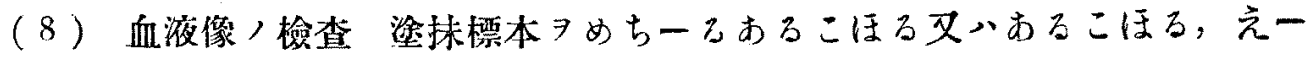
てる等分液 個以上檢查ノ本均數

（9）脾臟剔出法 えーてろ 以以ラ家鬼

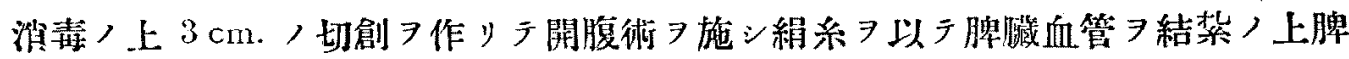

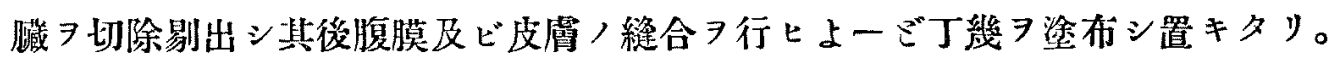

\section{實 驗 成 綪}

\section{1. 傅貧病馬血液接種家鬼二於ケル检查所見}

第 1 例 第 1 號家兔, 怢, 白, 體重 $1780 \mathrm{~g}$.（開始月日）昭和 2 年 4 月 9 日 （嗮備檢查）體溫 38 度赤血球 5,100,000 白血球 8,000 血色素 $62 \%$ 血液價 11.4 度（血液接種）友桑號血液 10.0 c.c. 耳静尿内泩入接種後 10 日 少 7 來シ 8 日間繼䜌 (本檢查) 體溫 38 度 5 分赤血球 $5,210,000$ 白血球 14,800 血色素 $71 \%$ 血液價 13.6 度ナy（結果）體温 0.5 度增加，赤血球 110,000 增 加, 白血球 6,800 增加血色素 9 \% 櫭加血液價 2.6 度增加。

第 2 例 第 2 號家克，牡，白，體重 $1,950 \mathrm{~g}$.（開始月日）昭和 2 年 4 月 9 日 （秝備檢查）體溫 38.4 度赤血球 $5,240,000$ 白血球 10,400 血色素 $65.5 \%$ 血液價 12.5 度（血液接種）遠野號血液 10.0 c.c. 耳静脉內注入接棰後 11 日 9 赤血球 ノ減少 7 認メ 11 日間繼續 (本檢查) 體温 39 度 7 分赤血球 $5,240,000$ 白血 球 9,800 血色素 $80 \%$ 血液價 15.2 度 (結果) 體溫 1.3 度增加赤血球賭減ナシ 白血球 600 娍少血色菜 $14.5 \%$ 增加血液價 2.7 度增加。

第 3 例 第 3 號, 壮, 日, 體重 $2,020 \mathrm{~g}$. (開始月日) 昭和 2 年 4 月 9 日（预備檢 查)體溫 37.6 度赤血球 5,350,000 白血球 11,000 血色素 $67 \%$ 血液價 12.5 度(血

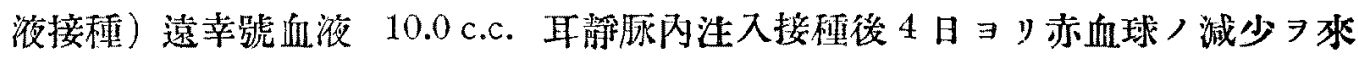


シ 12 日間繼續, (本檢查) 體温 39 度赤血球 4,300,000 白血球 13,200 血色素 $70 \%$ 血液價 16.3 度 (結果) 體溫 1.4 度增加, 赤血球 $1,050,000$ 娍少白血球 2,200 睤加血色素 3:\%增加血液價 3.8 度增加。

第 4 例 第 4 號,牡, 白,體重 $2,120 \mathrm{~g}$. (開始月日) 昭和 2 年 6 月 17 日（豫備檢 查）體溫 39 度赤血球 5,400,000 白血球 13,000 血色素 $75.5 \%$ 血液價 14.0 度 (血液接種)高田號血液 10.0 c.c. 耳静脉內注入接㮔後 7 日 ヨリ赤血球／減少アリ 6 日間繼絁 (本檢查) 體温 41 度赤血球 4,710,000 白血球 12,000 血色素 $67 \%$ 血液價 14.2 度 (結果) 體溫 2.0 度增加赤血球 690,000 減少日血球 1,000 減少 血色素 $8.5 \%$ 減少血液價 0.2 度增加。

第 5 例 第 5 號, 怢, 白, 體重 $1,884 \mathrm{~g}$. (開始月日).炤和 2 年 6 月 17 日(豫備檢 查）體溫 39.2 度赤血球 5,550,000 白血球 13,000 血色素 $67 \%$ 血液償 12.1 度 (血液接種)福墨號血液 10.0 c.c. 耳静䐂內泩入接種後 2 日

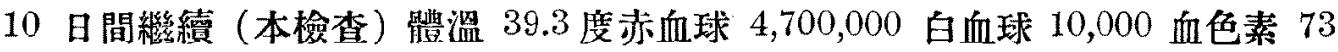
$\%$ 血液價 15.5 度 (結果) 體溫 0.1 度增加赤血球 850,000 減少白血球 3,000 減 少血色素 $6 \%$ 增加血液價 3.4 度增加。

第 6 例 第 6 號, 壮, 白, 體重 $1,976 \mathrm{~g}$ （開始月日）昭和 2 年 6 月 17 日（像備 檢查）體溫 38.4 度赤血球 4,500,000 白血球 9,000 血色素 $61 \%$ 血液價 13.6 度 (血液接種) 武婪號血液 10.0 c.c. 耳静胀內泩入, 接種後 2 日 $ョ$ y赤血球ノ減 少 7 來 $ン 7$ 日間繼續（本檢查）體溫 38.7 度赤血球 4,450,000 白血球 8,400 血 色素 $55.2 \%$ 血液價 12.4 度 (結果) 體溫 0.3 度增加赤血球 50,000 減少白血 球 600 減少血色素 $5.8 \%$ 減少血液價 1.2 度減少。

第 7 例 第 7 號,牡, 白, 體重 $2,004 \mathrm{~g}$. (開始月日) 昭和 2 年 9 月 7 日（预僙檢 查）體溫 38.1 度赤血球 5,160,000 白血球 10,560 血色素 $60.5 \%$ 血液價 11.7 度(血液接種)七戶號血液 5.0 c.c. 耳静脉內泩入接種後 4 日 9 赤血球／減少厂 y 6 日間繼續 (本撿査) 體溫 37.7 度赤血球 4,250,000 白血球 10,240 血色素 $56 \%$ 血液價 13.2 度 (結果) 體溫 0.4 度減少赤血球 910,000 減少白血球 320 減少血色素 $4.5 \%$ 減少血液價 1.5 度增加。

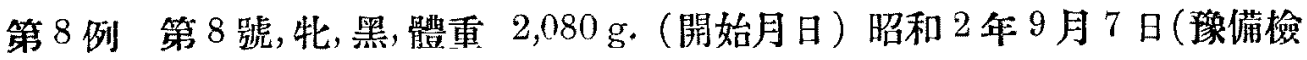
查）體溫 38.1 度赤血球 5,400,000 白血球 10,600 血色素 $57.3 \%$ 血液價 10.6 度（血液接種）七戶號血液 7 c.c. 耳静䐂內泩入接種後 2 日 ヨ赤血球ノ減少ア 
リ11 日間繼續 (本檢查) 體溫 38.7 度赤血球 4,480,000 白血球 9,520 血色素 $60.2 \%$ 血液價 13.4 度 (結果) 體温 0.6 度增加赤血球 920,000 減少白血球 1,080 減少血色素 $10.1 \%$ 減少血液價 2.8 度增加。

第 9 例 第 9 號伦, 白黑, 體重 $1,970 \mathrm{~g}$. (開始月日) 昭和 2 年 12 月 4 日 (腹備檢查) 體溫 38.2 度赤血球 4,400,000 白血球 16,000 血色素 $61 \%$ 血液價 13.8 度 (血液接種) 東獾號血液 7.0 c.c. 耳静脉內注入接種後 2 日 $\exists$ 赤血球

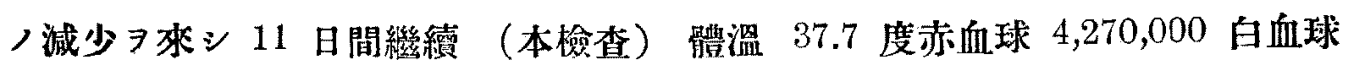
20,000 血色素 $61 \%$ 血液價 14.2 度 (結果) 體溫 0.5 度減少赤血球 130,000 減 少白血球 4,000 增加血色素變化 7 認メズ血液價 0.3 度瞔加。

第 10 例 第 10 號,牡, 白, 體重 $2,108 \mathrm{~g}$. (開始月日) 昭和 2 年 12 月 4 日（豫 仵检查）體溫 38.2 度赤血球 $5,900,000$ 白血球 20,200 血色素 $68 \%$ 血液價 11.5

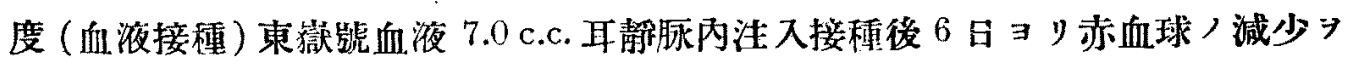
認丈9 日間繼續 (本檢查) 體溫 38.7 度赤血球 4,880,000 白血球 20,800 血色 素 $73.5 \%$ 血液價 15.0 度 (結果) 體溫 0.5 度習加赫血球 $1,020,000$ 減少白血 球 600 增加血色素 $5.5 \%$ 堵加血液價 3.5 度增加。

第 11 例第 11 號,比, 白,體重 $2,168 \mathrm{~g}$. (開始月日) 炤和 3 年 2 月 23 日（豫 借檢盉）娟溫 39.3 度赤血球 $6,350,000$ 白血球 19,500 血色素 $88 \%$ 血液價 13.9 度 (血液接種) 南極號血淮 8.0 c.c. 皮下注射接㮔後何等赤血球ノ異常シ求サズ 体ッラ 3 週間/本檢査期間/本均數 $6,570,000$ 白血球 23,000 血色素 $88.8 \%$ 血液價 13.5 度（結果）體温 0.1 度減 少赤血球 220,000 增加白血球 3,500 坦加血色素 $0.7 \%$ 堆加血液價 0.4 度減少。 第 12 例第 12 號, 牞, 白黑, 體重 $2,142 \mathrm{~g}$. (開始月日) 昭和 3 年 2 月 22 日 （豫借檢查）體溫 39.4 度赤血球 4,800,000 白血球 17,000 血色素 $87 \%$ 血液價 18.3 度 (血液接種) 南極號血液 8.0 c.c. 皮下注射接㮔後赤血球／減少 7 來サザ ルノミナラズ却ツテ上昇セリ故二本檢查成績ニメ3 週間/本圴习示セり（本檢 查）體溫 38.2 度赤血球 $5,160,000$ 白血球 13,100 血色素 $88 \%$ 血液價 17.0 度 （結果）體溫 1.2 度減少赤血球 360,000 赌加白血球 3,900 減少血色素 $1 \%$ 增 加, 血液價 1.3 度減少。

第 13 例 第 13 號, 牞, 白, 體重 $1,765 \mathrm{~g}$. (開始月日) 昭和 2 年 12 月 6 日(榢 備檢查）體温 39.1 度赤血球 $6,740,000$ 白血球 8,120 血色素 $59 \%$ 血液價 11.4 
度（血液接種）福墨號血液 10.0 c.c. 復腔內注入接種後 5 日 アy 10 日間繼續入 (本检査) 體溫 38.7 度赤血球 5,730,000 白血球 8,140 血 色素 $59 \%$ 血浚價 10.4 度 (結果) 體温 0.4 度減少赤血球 $1,010,000$ 減少白血 球 20 娍少血色素變化ナシ，血液價 1.0 度娍少。

第 14 例 第 14 號, 牞, 白, 體重 $2,150 \mathrm{~g}$. (開始月日) 昭和 2 年 12 月 8 日（豫 備檢查）體溫 39.1 度赤血球 $5,680,000$ 白血球 7,000 血色素 $53 \%$ 血液價 11.0 度 (血液接種) 福墨號血液 10.0 c.c. 腹腔內注入模種後 2 日ヨy赤血球ノ減少厂 y13 日間繼續 (本檢查) 體溫 39.0 度赤血球 4,960,000 白血球 8,180 血色素 $53.2 \%$ 血液價 10.7 度 (結果) 體溫 0.1 度減少赤血球 720,000 減少白血球 1,180 管加血色素 0.2 增加血液價 0.7 度增加。

2. 對照馬血液接種家兔所見

A. 非傳貧病墨 (腺疫) 血液接理家鬼二於ヶル血液檢查所見

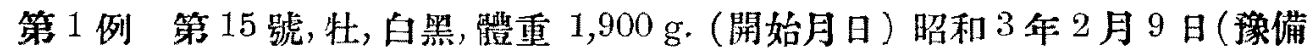
檢查）體溫 38.5 度赤血球 5,030,000 白血球 7,000 血色素 $70 \%$ 血液價 13.9 度

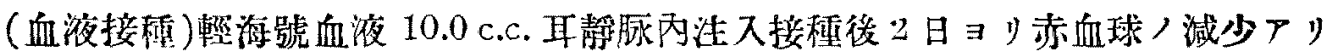

11 日間繼續（本檢查）體溫 38.4 度赤血球 4,700,000 白血球 10,000 血色素 74 $\%$ 血液價 15.7 度（結果）體溫 0.1 度減少赤血球 330,000 減少白血球 3000 增 加血色素 $4 \%$ 增加血液僄 1.8 度增加。

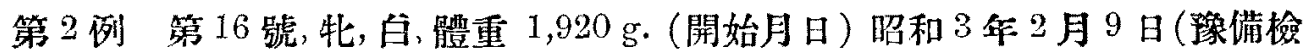
查）體溫 39.1 度赤血球 5,340,000 白血球 15,000 血色素 $77 \%$ 血液價 14.4 度

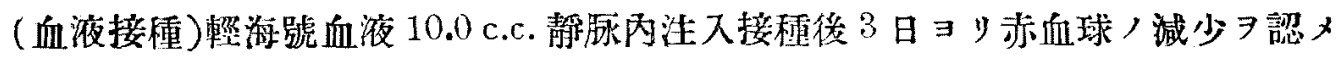
6 日間繼續 (本檢査) 體溫 39.0 度赤血球 5,340,000 白血球 11,500 血色素 78 $\%$ 血液價 14.7 度 (結果) 體溫 0.1 度減少赤血球變化ナシ白血球 3,500 減少血 色素 $1 \%$ 增加血液價 0.3 度增加。

第3 例 第 17 號,牝, 白,體重 $1,900 \mathrm{~g}$. (開始月日) 昭和 3 年 2 月 18 日(豫備 檢查）體溫 38.2 度赤血球 $6,000,000$ 白血球 12,000 血色素 $82 \%$ 血液價 13.7 度 (血液接種) 章駒號血液 8.0 c.c. 皮下泩射接種後 10 日ヨリ赤血球／減少アリ 7 日間繼續 (本檢查) 體溫 38.6 度赤血球 5,300,000 白血球 12,000 血色素 79 $\%$ 血液價 14.8 度 (結果) 體温 0.4 度䁌加, 赤血球 700,000 減少白血球變化ナ 洫色素 $3 \%$ 減少血液價 1.1 度增加。 
第 4 例 第 18 號, 㤌, 白, 體重 $2,012 \mathrm{~g}$. (開始月日) 昭和 3 年 2 月 23 日（豫備 檢查）體溫 38.6 度赤血球 $6,200,000$ 白血球 9,800 血色素 $80 \%$ 血液價 12.9 度 (血液接種) 公照號血液. 8.0 c.c. 腹腔內二泩入接種後 2 日ヨy赤血球ノ減少

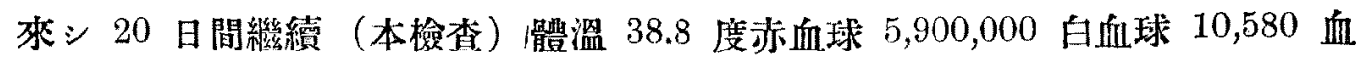
色素 $77 \%$ 血液價 13.1 度 (結果) 體溫 0.2 度增加, 赤血球 300,000 減少白血 球 780 增加血色素 $3 \%$ 減少血液價 0.2 度增加。

第 5 例 第 19 號, 比, 黑白, 體重 $1,910 \mathrm{~g}$. (開始月日) 昭和 3 年 2 月 23 日（踭 備檢查）體溫 38.8 度赤血球 $5,600,000$ 白血球 13,640 血色素 $74 \%$ 血液價 13.2 度 (血液接種) 公照號血液 8.0 c.c. 腹腔内泩入接種後 4 日 シ 8 日間繼續（本檢查）體溫 39.1 度赤血球 4,480,000 白血球 14,800 血色素 $69 \%$ 血液價 17.4 度（結果）體溫 0.3 度增加赤血球 $1,120,000$ 減少，白血球 1,160 增加血色素 $5 \%$ 娍少血液價 4.2 度堆加。

B. 健康馬血液接㮔家鬼所見

第 1 例 第 20 號, 牝, 野毛, 體重 $2,110 \mathrm{~g}$ （開始月日）炤和 2 年 12 月 10 日 （觹備檢查）體溫 38.8 度赤血球 5,650,000 日血球 9,000 血色素 $59 \%$ 血液價 10.5 度（血液接程）第 11 號血液 10.0 c.c. 耳靜䐂內洼入接㮔後 5 日 八減少アリ10日間繼續（本檢查）體溫 38.8 度赤血球 $4,810,000$ 白血球 11,580 血色素 $60 \%$ 血液價 12.5 度 (結果) 體温變化ナシ，赤血球 840,000 減少白血 球 2,580 增加, 血色素 $1 \%$ 增加血液價 2.0 度垬加。

第 2 例第 21 號,牝, 白, 體重 $2,090 \mathrm{~g}$. (開始月日) 昭和 3 年 2 月 23 日（豫備 憸查）體溫 38.2 度赤血球 4,700,000 白血球 19,400 血色素 $68 \%$ 血液傊 14.4 度

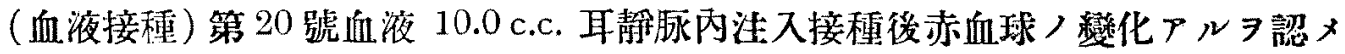
ズ故二本检查成績 接種後 3 週間ノ本圴 7 示七り（本檢查）體溫 38.6 度赤血 球 $5,070,000$ 白血球 21,200 血色素 $70 \%$ 血液價 13.8 度（結果）體溫 0.4 度 增加赤血球 370,000 䝬加白血球 1,800 增加，血色素 $2 \%$ 增加血液價 0.6 度減少。

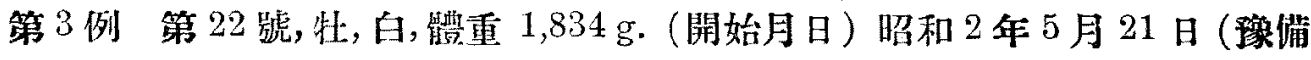

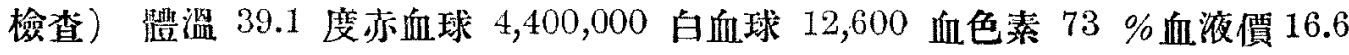
度 (血液接理) 第 18 號血液 10.0 c.c. 皮下注射接種後 2 日 $コ$ 浾血球ノ減少 y 4 日間繼續 (本檢查) 體溫 39.4 度赤血球 $3,440,000$ 白血球 10,800 血色素 $44.8 \%$ 血液價 13.0 度 (結果) 體溫 0.3 度增加赤血球 960,000 減少白血球 1,800 
娍少血色素 $28.2 \%$ 減少血液價 3.6 度減少。

第 4 例 第 23 號, 比, 白, 體重 $1,096 \mathrm{~g}$. (閶始月日) 昭和 3 年 2 月 23 日（豫備 檢查）體溫 38.6 度赤血球 $5,500,000$ 白血球 9,500 血色素 $77 \%$ 血液價 14.0 度 （血液接種）第 20 號血液 8.0 c.c. 皮下泩射接種後 2 日ヨy赤血球，減少厂y 14 日間繼續, (本检查)唱溫 39.4 度, 赤血球 5,300,000 白血球 10,800 血色素 76 $\%$ 血液價 14.3 度 (結果) 體溫 0.8 度增加赤血球 200,000 減少白血球 1,300 增 加, 血色素 $1 \%$ 娍少血液價 0.3 度增加。

第 5 例 第 24 號, 壮, 白, 體重 $2,080 \mathrm{~g}$. (開始月日) 昭和 2 年 8 月 15 日（豫满 檢查）體溫 38.5 度赤血球 5,280,000 白血球 15,500 血色素 $53 \%$ 血液價 10.0 度（血液接種）第 20 號血液 10.0 c.c. 腹腔內汪入接種後 3 日 アリ 3 日間繼續 (本檢査) 體溫 38.2 度赤血球 4,950,000 白血球 12,000 血色素 $55 \%$ 血液價 11.5 度 (結果) 體溫 0.3 度減少赤血球 330,000 減少, 白血球 3.500 隇少血色素 $2 \%$ 增加血液價 1.5 度霄加。

3. 脾臟剔出家兔二傳貧馬血液接程後二於ケル血液檢査所見

第 1 例第 30 號,牡, 白, 體重 $2,240 \mathrm{~g}$.（開始月日）炤和 2 年 5 月 14 日（脾

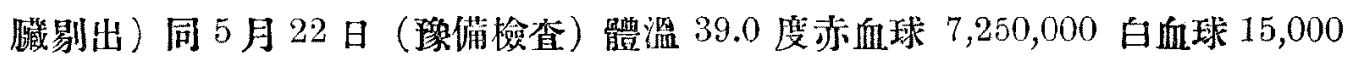
血色素 $72 \%$ 血液價 9.9 度(血液接枉)高田號血液 8.0 c.c. 耳静陦队泩入接種後 2

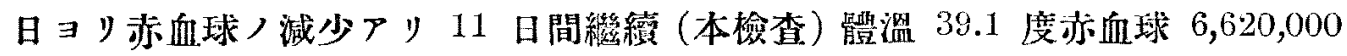
白血球 10,540 血色素 $65 \%$ 血液價 9.85 度（結果）體溫 0.1 度䝬加, 赤血球 630,000 減少白血球 4,460 減少血色素 $7 \%$ 減少血液價 0.05 度減少。

第 2 例 第 31 號, 牳, 白, 體重 $1.920 \mathrm{~g}$. (開始月日) 昭和 2 年 6 月 15 日（脾藏 剔出）同月 23 日（镍備檢查）嘈溫 39.4 度赤血球 5,730,000 白血球 14,000 血 色素 $72.5 \%$ 血液價 12.6 度(血液接種) 福墨啹血液 8.0 c.c. 耳静脉內注入接㮔後 3 日ョリ赤血球ノ減少アリ 10 日間繼續, (本檢查) 體溫 39.2 度赤血球 4,650,000 白血球 11,600 血色素 $67.7 \%$ 血液價 14.3 度 (結果) 體溫 0.2 度減少赤血球 1,070,000 減少白血球 2,400 減少, 血色素 $4.8 \%$ 減少血液價 1.7 度增加。

第 3 例 第 32 號, 牝, 白, 體重 2,120g.（開始月日）昭和 2 年 2 月 21 日（脾藏 剔出）同月 28 ，日（豫備檢查）體溫 37.8 度赤血球 4,960,000 白血球 10,800 血 色素 $65.8 \%$ 血液價 13.3 度（血液接種）さんぱれい號血液 8.0 c.c. 耳静䐂內注

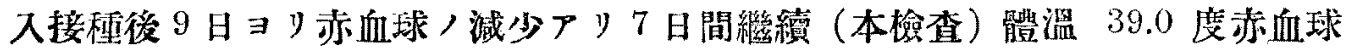


4,650,000 白血球 10,000 血色素 $66 \%$ 血液價 14.2 度 (結果) 體温 1.2 隻墦加 赤血球 310,000 娍少白血球 800 減少血色素 $0.2 \%$ 塯加血液價 0.9 度增加。

第 4 例 第 33 躆, 牡, 白黑, 體重 $2,118 \mathrm{~g}$. (開始月日) 昭和 2 年 2 月 21 日（脾

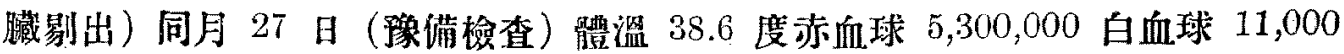
血色素 $67 \%$ 血液價 12.6 度（血液接程）扣一ばいやん號血液 10.0 c.c. 皮下泩

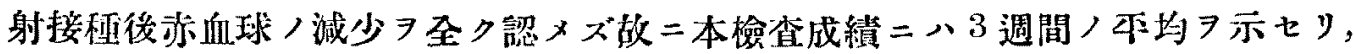
（本檢查）體溫 38.5 度赤血球 $5,350,000$ 白血球 12,000 血色素 $70 \%$ 血液價 13.1 度 (結果) 䯣溫 0.1 度減少赤血球 50,000 增加白血球 1,000 增加血色素 $3 \%$ 增 加，血液價 0.5 度增加。

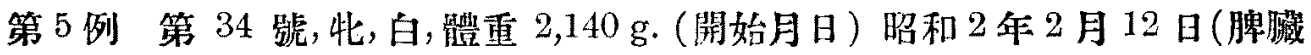

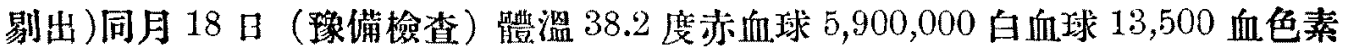

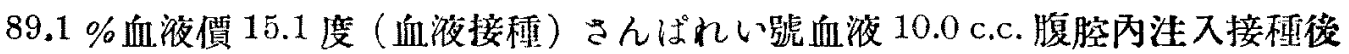

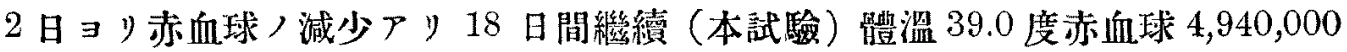
白血球 17,300 血色素 $83.3 \%$ 血液價 16.8 度（結果）體溫 8 度增加赫血球 960,000 減少白血球 3,600 增加血色素 $5.8 \%$ 減少血液價 1.7 度習加。

4. 脾臟剔出家鬼二對照熙血液接種後二於ル血液检查所見。

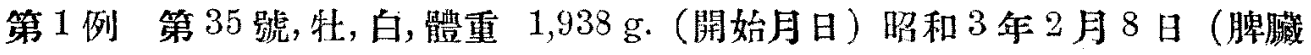
剔出)同月 20 日（㐨借檢查）㗐温 38.4 度赤血球 $7,470,000$ 白血球 9,700 血色

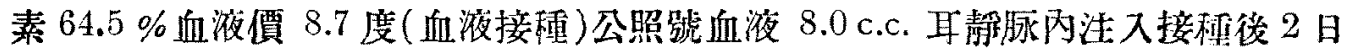
ヨリ赤血球/減少 $\exists$ 承シ 21 日間繼續（本檢查）體溫 39.4 度赫血球 4,850,000 白血球 10,100 血色素 $71.1 \%$ 血液價 14.6 度 (結果) 體溫 1.0 度墦加赤血球 2,620,000 減少白血球 400 增加血色素 $5.6 \%$ 增加血洐價 5.9 度增加。

第 2 例 第 36 號, 牞, 白, 體重 $1,981 \mathrm{~g}$. (開始月日) 昭和 3 年 2 月 8 日（脾臟剔

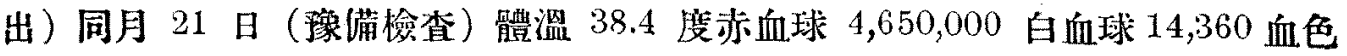
素 $72 \%$ 血液價 15.5 度 (血液接梗) 章駒號血液 8.0 c.c. 皮下注射接種偻赤血球

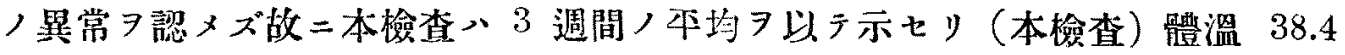
度赫血球 $5,200,000$ 日血球 14,400 血色素 $72 \%$ 血液䨘 13.8 度（結果）體賉 嘎化ナシ，赫血球 550,000 增加白血球 40 增加血色素變化ナシ，血液價 1.7 度 增加。

第 3 例 第 37 號, 靕, 白黑, 體重 $2,108 \mathrm{~g}$. (開始月日) 昭和 3 年 2 月 23 日（脾 


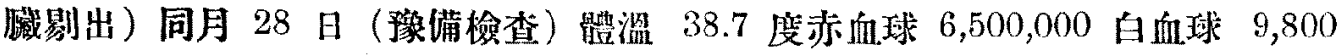
血色素 $67 \%$ 血腹價 10.3 度（血液接種）第 18 號馬血液 8.0 c.c. 皮下泩射接種 後赤血球ノ買狀 $\ni$ 認メズ (本檢查) 䯣溫 38.4 度赫血球 6,500,000 白血球 10,900 血色素 $67 \%$ 血液價 10.3 度（結果）呺唺溫 0.3 度減少赤血球，血色素及血液價 答化ナシ，白血球 290 筧加。

第 4 例 第 38 號，牡，野毛，喅重 $1,820 \mathrm{~g}$ （開始月日) 昭和 2 年 5 月 21 日 (脾莜剔出) 同 21 日（豫備檢查）體溫 39.4 度赤血球 $5,100,000$ 白血球 15,600 血色素 $98 \%$ 血液價 19.2 度 (血液接棰) 第 17 號血液 10.0 c.c. 静胍内泩入接 種後 2 日ヨリ赤血球ノ減少アリ 4 日間繼續（本檢查）體溫 38.9 度赤血球 $3,960,000$ 白血球 16,000 血色素 $83 \%$ 血液價 25.0 度（結果）體溫 0.5 度減少 赤血球 1,040,000 減少白血球 400 賟加血色素 $15 \%$ 減少血液價 5.8 度賭加。

第 5 例 第 39 號, 牝, 白, 體重 $2,132 \mathrm{~g}$. (開始月日) 昭和 3 年 2 月 23 日（脾臟 剔出）同月 28 日（豫備检查）體温 38.2 度赤血球 5,930,000 白血球 15,800 血 色素 $79 \%$ 血液價 13.3 度（血液接種）第 20 號血液 8.0 c.c. 静疗內泩入接種後 2 日 $ヨ$ 赤血球ノ減少厂y 7 日間繼續（本檢查）體溫 38.6 度赤血球 5,920,000 白血球 16,000 血色素 $80 \%$ 血液價 13.5 度（結果）體溫 0.4 度增加赤血球 10,000 減少白血球 200 增加血色素 $1 \%$ 增加血液價 0.2 度增加。

5. 無處置家㐓二於ケル血液檢查所見

第 1 例 第 25 號,牡, 白, 體重 $1,880 \mathrm{~g}$. (檢查期間) 昭和 2 年 9 月 14 日ョり 1

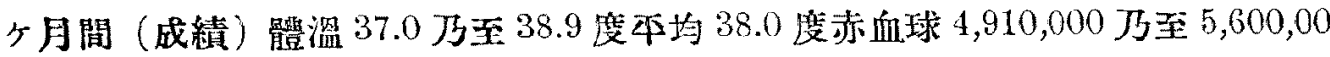
平均 5,220,000 日血球 9,800 乃至 10,480 本均 10,230 血色素 58 乃至 $70 \%$ 平均 $65.2 \%$ 血液價平均 12.5 度。

第 2 例、第 26 號，牡，白，體重 $1,830 \mathrm{~g}$. (儉查期間) 昭和 2 年 10 月 18 日 ヨy 1 个月間 (成績) 體温 37.0 乃至 38.4 度平均 37.7 度赤血球 $3,800,000$ 乃至 $4,420,000$ 平均 4,210,000 白血球 15,200 乃至 21,200 本均 18,000 血色素 59 乃至 $65.1 \%$ 本均 $62 \%$ 血液價平均 14.7 度。

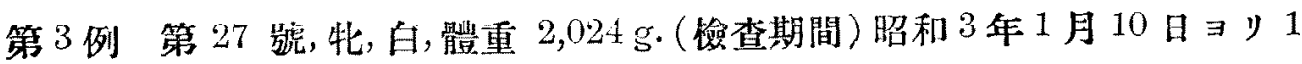
ケ月間 (成績) 體溫 37.6 乃至 38.6 度本均 38.2 度赤血球 $4,700,000$ 乃至 $5,610,000$ 平均 5,220,000 白血球 10,000 乃至 13,800 本均 12,200 血色素 59 乃至 $67 \%$ 平均 $63 \%$ 血旅價平均 12.1 度。 
第 4 例 第 28 號,比, 白, 體重 $2,124 \mathrm{~g}$. (檢查期間) 昭和 3 年 1 月 10 日ョ》1 5月間 (成綪) 體温 37.8 万至 38.6 度本均 38.2 度赤血球 $5,700,000$ 万至 $6,660,000$ 本均 $5,840,000$ 白血球 10,000 乃至 15,000 平均 13,400 血色素 78 乃至 $85 \%$ 平均 $80.2 \%$ 血液價本均 13.8 度。

第 5 例 第 29 號,北, 白, 體重 $2,120 \mathrm{~g}$. (檢查期間) 昭和 3 年 1 月 16 日ョリ 1 ケ月間 (成綪) 娟温 37.5 乃至 38.6 度本均 38.2 度赤血球 $5,700,000$ 乃至 $6,300,000$ 本均 6,100,000 白血球 11,000 乃至 13,000 本均 12,300 血色素 68 乃至 $90 \%$ 平均 $85.1 \%$ 血液價本均 13.9 度。

第 6 例 第 40 號，牡，白黑, 體重 $2,000 \mathrm{~g}$. (檢査期間) 昭和 3 年 1 月 16 日 1 ケ月間（成績）體溫 37.4 乃至 38.8 度尔均 38 度赤血球 $5,400,000$ 乃至 6,610,000 平均 6,100,000 白血球 8,000 乃至 13,000 本均 11,000 血色素 78 乃 至 $84 \%$ 平均 $81 \%$ 血液價本均 13.3 度。

\section{5. 成 績 表}

師チ上述セル諸實驗ノ示ス結果 1 表トシテ相對比スレド次ノ如シ。

\begin{tabular}{|c|c|c|c|c|c|c|c|c|c|c|c|c|c|c|}
\hline \multicolumn{2}{|c|}{$\left|\begin{array}{cc}t^{6} & \text { 置|家鬼 } \\
\text { 方 } & \text { 法番號 }\end{array}\right|$} & 性 & $\begin{array}{l}\text { 體 重 } \\
(g r .)\end{array}$ & $\begin{array}{l}\text { 接 } \text { 種 } \\
\text { 血 液 }\end{array}$ & $\begin{array}{l}\text { 接種 } \\
\text { 部位 }\end{array}$ & $\begin{array}{l}\text { 接種量 } \\
\text { (c.c.) }\end{array}$ & $\begin{array}{l}\text { 䯠 温 } \\
\left(\mathrm{C}^{\circ}\right)\end{array}$ & \multicolumn{2}{|c|}{$\begin{array}{c}\text { 赤血球 } \\
\text { (蕺) }\end{array}$} & 白血球 & $\begin{array}{c}\text { 血色素 } \\
(\%)\end{array}$ & \multicolumn{2}{|c|}{$\begin{array}{c}\text { 血液䀺 } \\
\text { (度) }\end{array}$} & $\begin{array}{l}\text { 物 } \\
\text { 定 }\end{array}$ \\
\hline \multirow{3}{*}{ 傳 } & 1 & $\hat{s}$ & 1,780 & 友 桑 & 静脈 & 10.0 & 0.5 & + & 11 & $+6,800$ & 9.0 & + & 2.6 & - \\
\hline & 2 & 占 & 1,950 & 遠 野 & $" \prime$ & 10.0 & +1.3 & & 0. & 600 & +14.5 & + & 2.7 & \pm \\
\hline & 3 & $\hat{\sigma}$ & 2,120 & 遠 幸 & $\prime \prime$ & 10.0 & $+\quad 1.4$ & - & 105 & $+2,200$ & 3.0 & + & 3.8 & 卅 \\
\hline 凟 & 4 & 今 & 2,120 & 高 田 & " & 10.0 & $+\quad 2.0$ & - & 69. & $-1,000$ & 8.5 & + & 0.2 & \pm \\
\hline 病 & 5 & 令 & 1,884 & 裸 墨 & 静脈 & 10.0 & +0.1 & - & 85 & $-3,000$ & 6.0 & + & 3.4 & \# \\
\hline \multirow[t]{2}{*}{ 桭 } & 6 & 今 & 1,997 & 武 安 & $" \prime$ & 10.0 & $+\quad 0.3$ & + & 5. & 600 & 5.8 & - & 1.2 & - \\
\hline & 7 & 古 & 2,004 & 七 & $" \prime$ & 5.0 & $-\quad 0.4$ & - & 91 & 320 & 4.5 & + & 1.5 & + \\
\hline 血. & 8 & 우 & 2,080 & " & " & 7.0 & 0.6 & - & 92 & $-1,000$ & -10.1 & + & 2.8 & H \\
\hline 液 & 9 & 우 & 1,970 & 東 狺 & " & $" 1$ & -0.5 & - & 13 & $+4,000$ & 0 & + & 0.3 & - \\
\hline 接 & 10 & 今 & 2,108 & 11 & " & $" \prime$ & $+\quad 0.5$ & - & 102 & 600 & 5.5 & + & 3.5 & m \\
\hline \multirow[t]{4}{*}{ 種 } & 11 & 우 & 2,168 & 南 極 & 皮下 & 8.0 & -0.1 & + & 22 & $+2,500$ & 0.7 & - & 0.4 & - \\
\hline & 12 & $\hat{\sigma}$ & 2,142 & " & " & " & $-\quad 1.2$ & + & 36 & $-3,900$ & 1.0 & - & 1.3 & - \\
\hline & 13 & 市 & 1,765 & 福 墨 & 腹膛 & 10.0 & $-\quad 0.4$ & - & 101 & 20 & 0 & - & 1.0 & $\#$ \\
\hline & 14 & $\widehat{\delta}$ & 2,150 & " & " & $\prime \prime$ & $-\quad 0.1$ & - & 72 & $+1,180$ & 0.2 & + & 0.7 & \pm \\
\hline
\end{tabular}




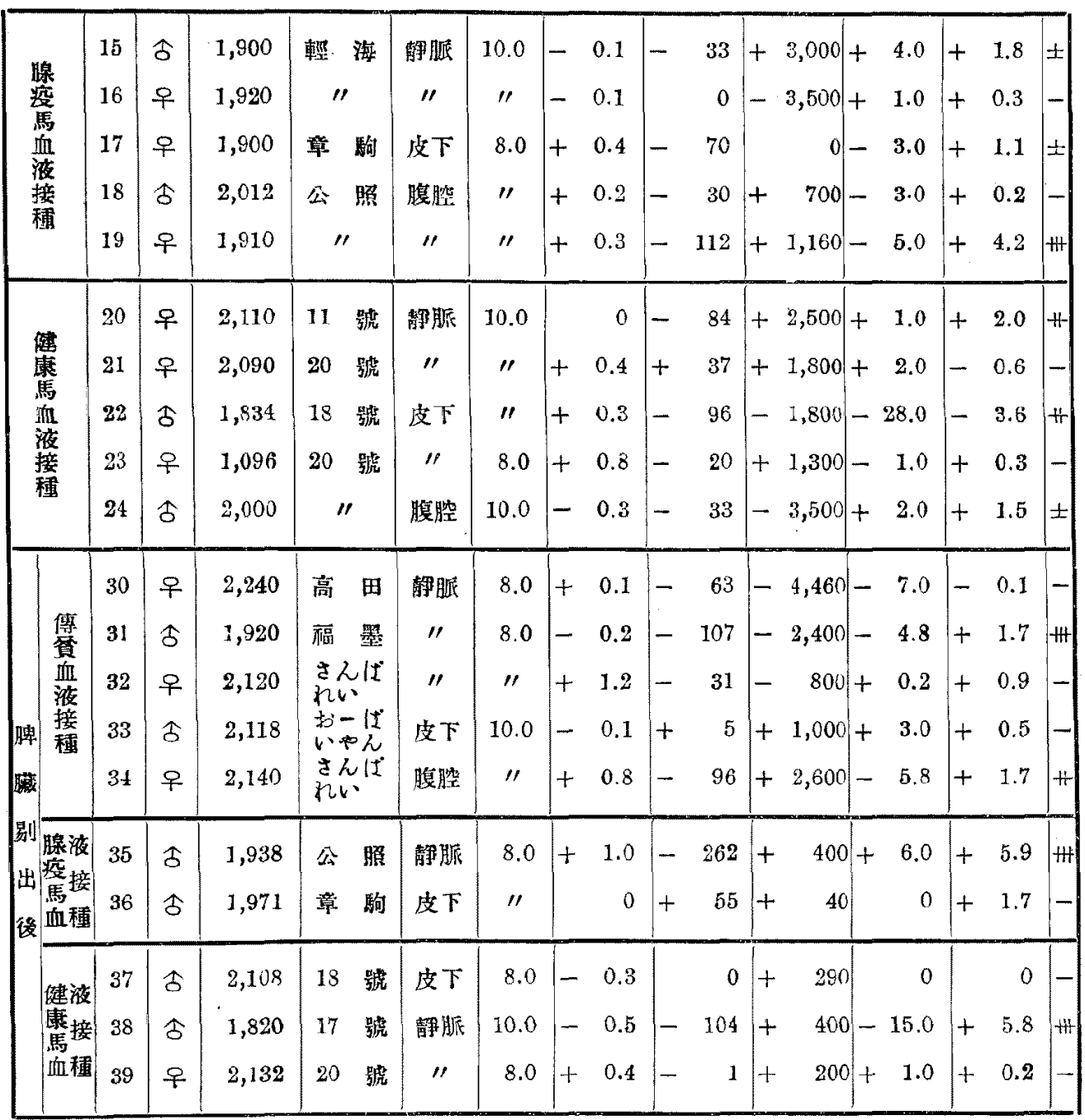

锶

括

\section{1. 一 般 狀 態}

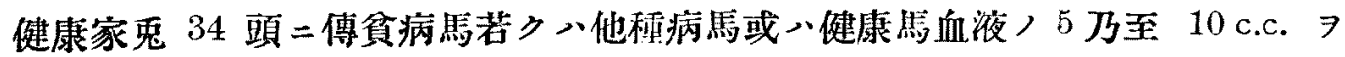

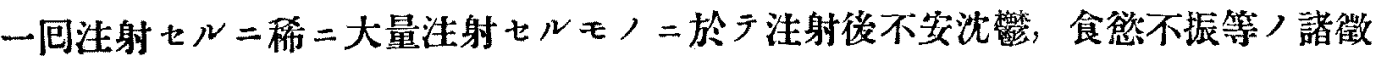

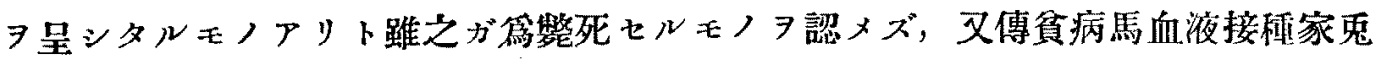

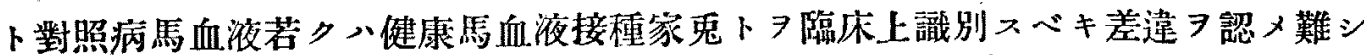
唒市井ヨリ購入セル家兔 状態不良トナリ抵抗力八減弱ヨ棑シこくしぢうむ症〉誘發又心签易二敗血症等二

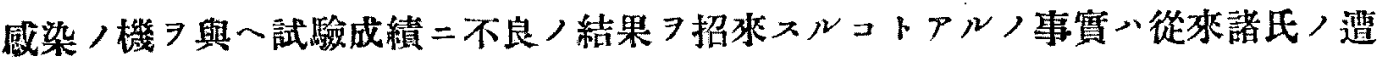




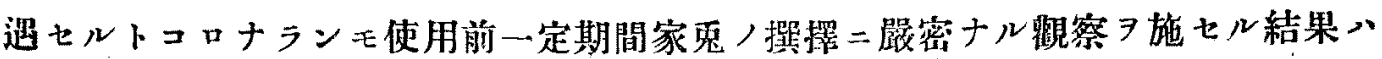

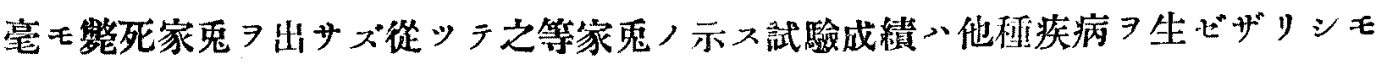

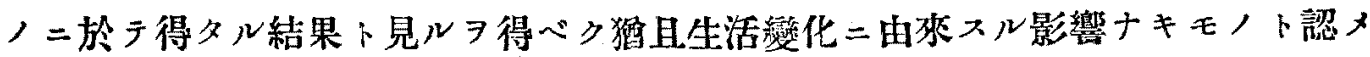
以下各實驗家鬼二就テ得タル檢查成綪习總括對比シテ示卡・スルモノナリ

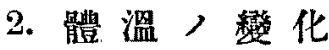

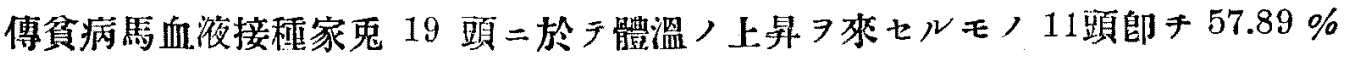
ニシテ平均 0.8 度ノ上景ナリ對照タル腺疾病馬血液及ビ健康馬血液接種家鬼 15 頭二於テ其ノ上昇アルモノ 8 頭即テ $53.33 \%$ ニテ本均 0.45 度ノ上昇ナリ又脾

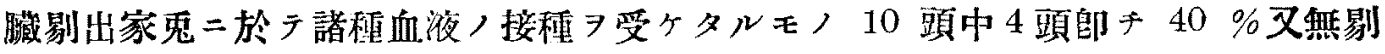

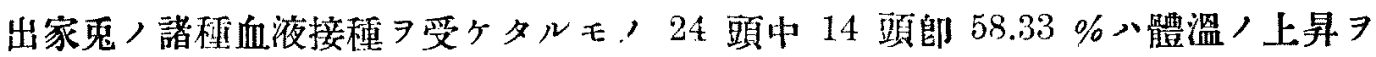
示セり反之全然未接種ノ健常家兔 6 頭二於テハ毫モ體䀀/變化ヨ呈セズ。

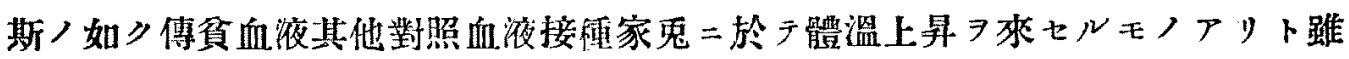
差溫二基ク識別ナシ難キノミカ雨者殆ド一致シラ美違ヨ認メズ又脾践剔出處置， 如何ニヨリ示サル、結果二モ老違

3. 赤血球數ノ變化即于減少 $ヨ$ 呈セルモノニッキ各種血液接種家鬼頭數ヨリ其 ノ比率 ノ最モ多ク 8 頭中 6 頭師チ $75.00 \%$ \%之二次グ 八傳賓病馬血液接種家鬼ニシテ

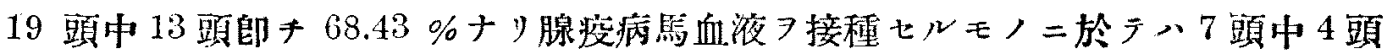

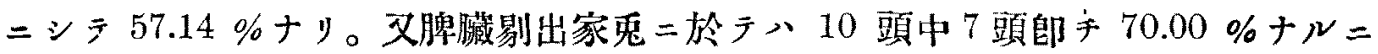
對シ無剔出家鬼ニアリシン 24 頭中 17 頭郎于 $70.83 \%$ 於ラ赤血球ノ娍少 7 示 セり。反之對照ト七ル無處置健康家兔二於テハ殆ド考慮メべキ增減ヨ認メズ。次

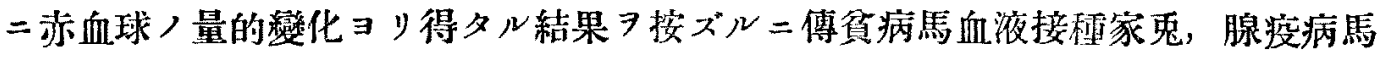
血液接理家兔及ビ健康馬血液接種家鬼八順位二於亏其八減少アルフ認ム。

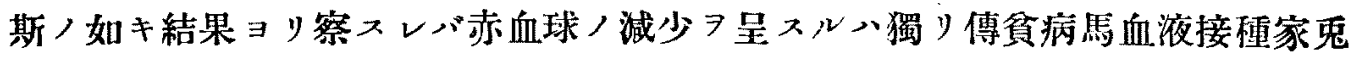
ニ於テノミ認ムべキ現像ナリト信ズルコト能・ズ是レ家兔二異種蛋白 7 非經口的 ニ注入スルトキ一般二赤血球/減少 7 認メタル Schermer 氏ノ實羷成績ト一致ス

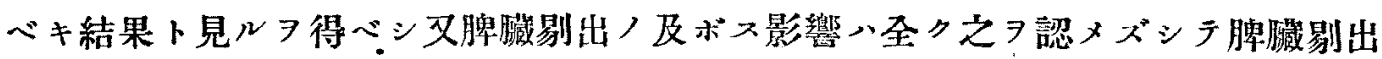
二基ク赤血球數ノ戀化ハ殆ド認メ得ザルノ所詥二一致セり。

4. 白血球數, 箖化

一般二各種血液接種家兔二於ラ白血球數 增加アルラ常トセリ，健康馬血液接 


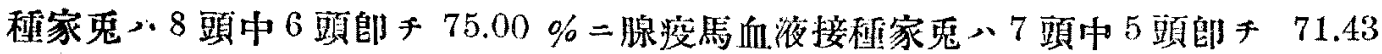

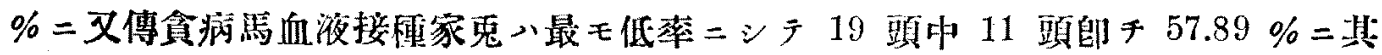

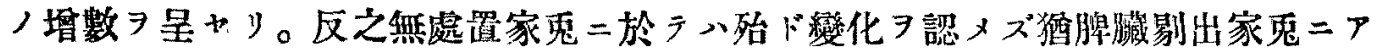
リラハ10頭中 7 頭二其ノ增加习認メタリ。

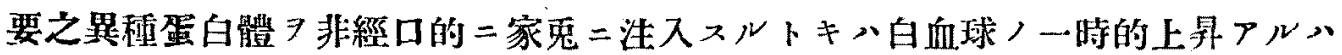

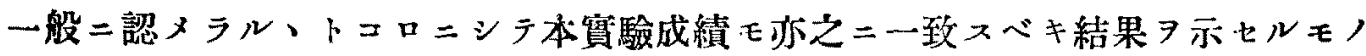
ト認メラル然ドモ傳貧病馬血液接種家兔卜對照タル他種血液接種家鬼卜ノ示ス數

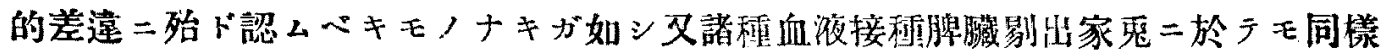
ナリ。

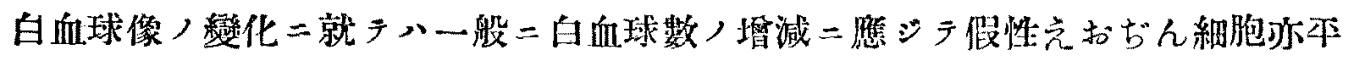
行シラ浮沈スルモ淋巴球數二メ美違ヨ來スコト少ナシト認么其他ノ各種白血球型

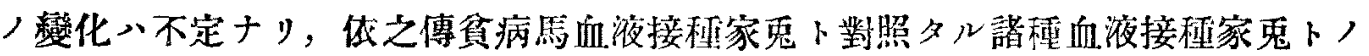
間二何等認ムベキ荎違ナキが如シ。

5. 血色素量, 變化

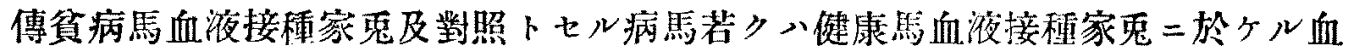
色素量ノ增減關係二就ラ・略同栐ノ成績

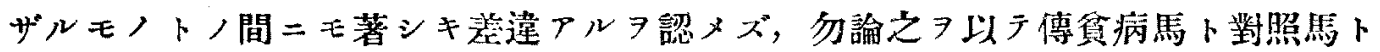
ノ鑑別ハ困難ナリ。

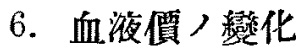

赤血球數ノ減少二對シテ血液價ノ上昨スルハ抵氏反照二於シ最モ特異ナリト指 示セラル、所ナリ。本實驗二於ケル各種血液接種家鬼/示ス結果ヨリ之 見ル時

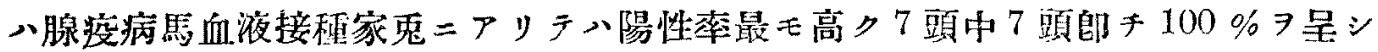

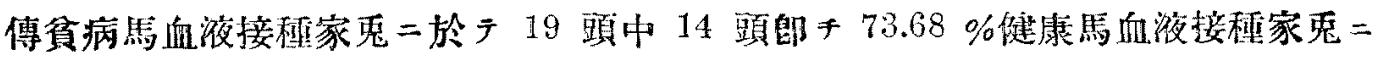
テハ 8 頭中 5 頭師チ $62.50 \%$ >陽性率 フ示セり。本實驗ヨり照合スルモ血液價

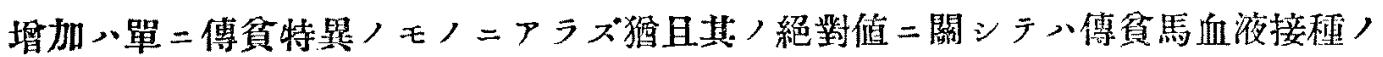
モノタルト健康馬血液接㮔ノモノタルト二於テ何等ノ特殊的弆造アルタ認メザル 二於ラオヤ。

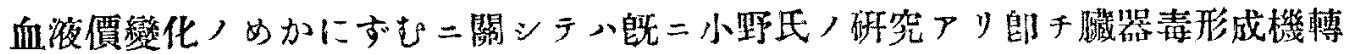
二起因スル剌战作用ナルモノ、如シ。

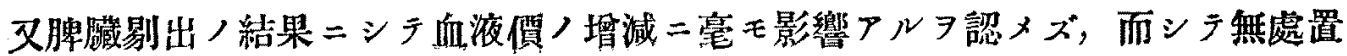


家鬼二於テハ血液價，唒減二砝ド認ムハモノナシ。

7. 动氏反摩成績, 制定

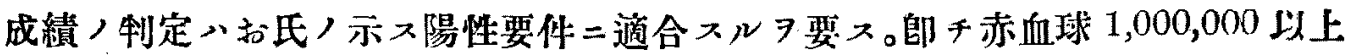
ノ減少 ヨ承シ其ノ前後一定期間之が持續 昇白血球ノ埥加及ビ著明ナル血液價ノ上昇曲線 7 示シ脾腫

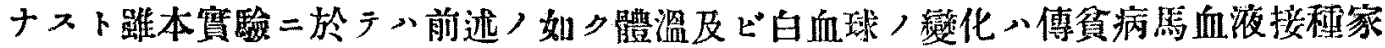

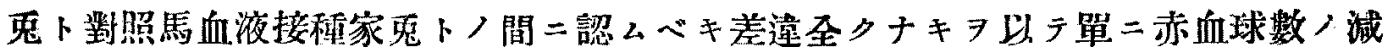
少ト血液價，上昇度トヨ對比シテ下ノ成績

（1）傳筫病馬及ビ對照馬血液接種家鬼二於ヶル反應比輤

\begin{tabular}{|c|c|c|c|c|c|c|c|c|}
\hline \multirow{2}{*}{ 直液别 } & \multirow{2}{*}{$\begin{array}{l}\text { 使 用 } \\
\text { 家鬼影 }\end{array}$} & \multicolumn{2}{|c|}{ 陽性成続 } & \multicolumn{3}{|c|}{ 成 } & \multicolumn{2}{|l|}{ 别 } \\
\hline & & 数 & $\%$ & (卅) & $(H)$ & $(+)$ & $( \pm)$ & $(-)$ \\
\hline 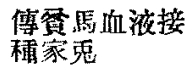 & 19 & 11 & 57.89 & 3 & 5 & - & 3 & 8 \\
\hline $\begin{array}{l}\text { 腺没病焉血液 } \\
\text { 接種家无 }\end{array}$ & 7 & 4 & 57.14 & 2 & - & - & 2 & 3 \\
\hline $\begin{array}{l}\text { 健康馬血液接 } \\
\text { 租家兔 }\end{array}$ & 8 & 4 & 50.00 & 1 & 2 & - & 1 & 4 \\
\hline 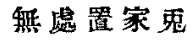 & 6 & - & 0. & - & - & - & - & 6 \\
\hline
\end{tabular}

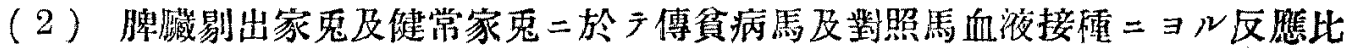
暒

\begin{tabular}{|c|c|c|c|c|c|c|c|c|}
\hline \multirow{2}{*}{ 成結别 } & \multirow{2}{*}{$\begin{array}{l}\text { 使 } \\
\text { 家兔數 }\end{array}$} & \multicolumn{2}{|c|}{ 晹性减績 } & \multicolumn{2}{|r|}{ 成 } & 絴 & \multicolumn{2}{|l|}{ 別 } \\
\hline & & 數 & $\%$ & (\#) & (H) & $(+)$ & $( \pm)$ & $(-)$ \\
\hline 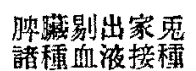 & 10 & 4 & 40.00 & 3 & 1 & - & - & 6 \\
\hline 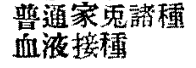 & 24 & 15 & 62.50 & 3 & 6 & - & 6 & 9 \\
\hline
\end{tabular}

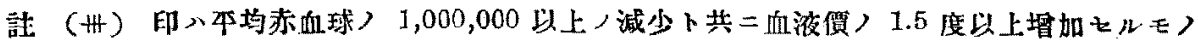

（H）印八平均赤血球，700,000 以上／減少卜共二血液價 1.5 度以上增加を心モ，

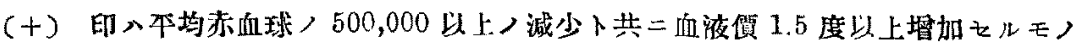

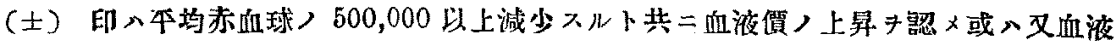
筫 1.5 度以上上昇 スル卜共二赤血球ノ減少をルモ，

（一）印八右條件二適合をザルモ）

結論

以上ノ貸驗成績

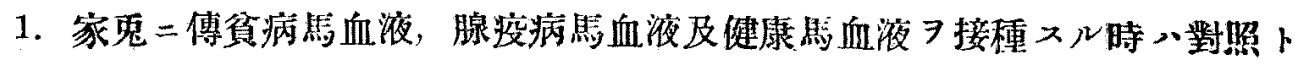


セル未接種家鬼ノ示ストコロ二全ク異りタル血液ノ變化即手赤血球數/減少及

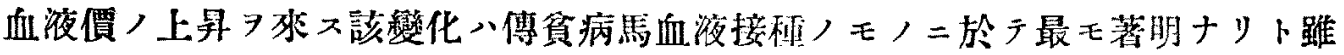

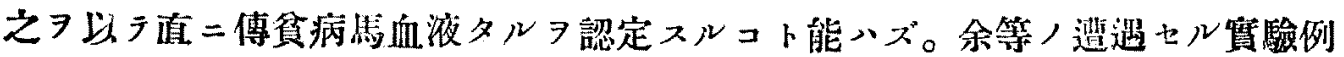
二於テモ傳顀病馬血液接種ノモノ二於于 $57.89 \%$ ，制合二之ヨ示スト共二又對 照馬血液接種家鬼二於テモ $57.14 \%$ 成績 $\ni$ 呈セり。

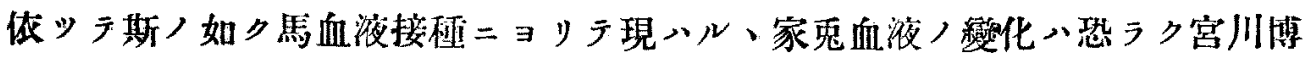

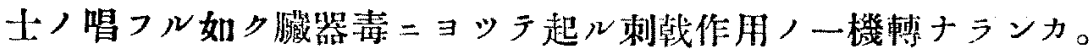

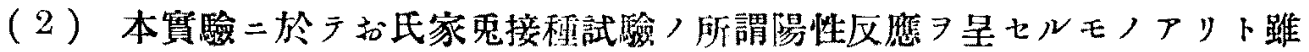

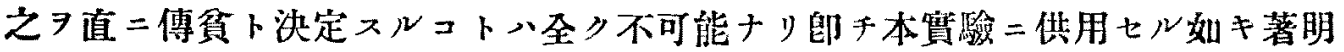
ナル傳貧發症馬血液ヨ以ラスラ $15.79 \%$ 陽性率ヨ示セルニ過ギズシラ對照タ ル腺疫馬血液接種家鬼二於テメ却ッラ之ヨリ高キ陽性萃ヨ呈セり郎キて頭ノ接

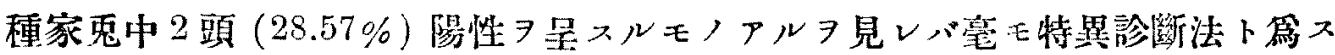

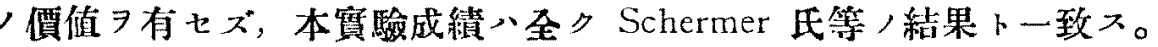

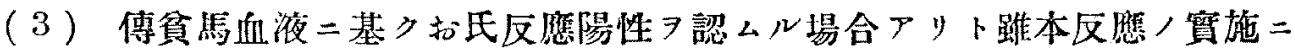
際シ少クトモ4 週日ノ觀察期間 フ要シ其ノ間連日又八隔日，檢查》多大／時間 ト勞力トニ加へラ相當熟練セル技術ヨ以ラセザレバ確賽ナル結果 以ラ臨床的憵用價傎極メラ少キモノト認ム。

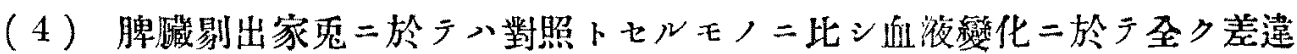
ヨ認メズシテ傅貧病馬血液接種試驗ニ之ヨ烣用スルノ價值ハ圣ク認ムルコト能 ハズ。

\section{Literatur.}

1. 臨時馬疫調查委員會研究成績 (第 3 軦) 大正 3 年

2. Jaffie u. Silberstein; Die Ubertragbarkeit der austerkenden Blutarmut der Pferde. Zeitscher f. exp. Medizin 1922. 26 Bd.

3. Oppermann u. Lanterbasch; Die Diagnose der infektiöne Anämie der Pferde durch den Kaninchenversuch, B. 'T. 2. XXXX. 1993. u. XXXX. 1924.

4. Standfuss; Zur Erkennung der austekenden Plutarmut des Pferdes durch den Kaninchen. Berliner Tierärztliche Woch. XXXIX 1923.

5. Helm; Die Diagnose der infektiösen Anämie des Pferdes auf Meerschweinchen u. Kaninchen. Archiv für wissenschaftliche u. Praktisshe Tierheillunde 1924. 51 Band.

6. Schuckman u. Karmenn; Die Diagnose der infektiösen Anämie der Pferde durch den Kaninchenversuch nach Oppermann. B. T. W. 1924, S. 497.

7. Ernst Forgel ; Das Verhalten des Virus der infektiösen Anämie des Pferdes bei Kanin- 
chenpassagcn. D. T. W. P 429, 1924.

8. Marbash, Ir; Rektale Infektion des Kaninchen mit dem Virus der infektiösen Anämie der Pferde. T, R. 1926, S 413.

9. Ziegler u. Grosse; Weitere Uuterschuchungen über die austeckende Blutarmut des Pferdes. Zsche, f. infekt, krkh, d, Hant, 1925, 27 S. 288.

10. Luhrs; Die Diagrnose der austeckenden Blutarmut nach Oppermann. B. T. W. XXXX, 1924.

11. F, Röber; ' Kaninchen-Pessageversuche mit dem Virus der ansteckenden Blutarmut der Pferde. B. T. W. 40, 1924.

12. G. Pallaske; Beiträre zur Diagnostick der infektiöse Anämie der Pferde mittels Kaninchenübertragensversuches. B. T. W. 40, 1924.

13. Schermer; Die histologische Veränderungen bei den infektiosen Anämie des Pferdes u. ihr Verzleich init denen bei experimentallen Anamien. Arsh. f. wiss. Tierheil Kunde.

14. Schermer u. Eigendorf: Die diagnostische Beutung des Kaninchenimpfversuchs bei der infektiösen Anïmie der Pferdes. Arch. f, wischenschaftiche und praktische Tierheilkunde 54, Bd, 1926.

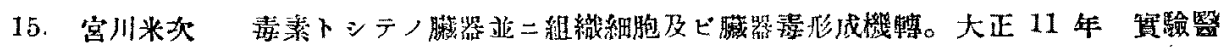
學會雔誌 第 6 管 籍 6 號

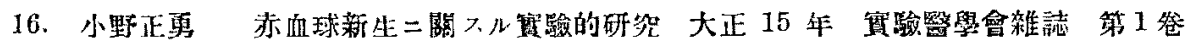
第 6 躆 


\title{
Zur Diagnose der ansteckenden Blutarmut des Pferdes durch den Kaninchenimpfversuch nach Oppermann.
}

\author{
Von \\ T. Nakamura, S. Matsuba, Y. Kawamura \\ und F. MIYAFAWA. \\ (Aus dem Veterinärlaboratorium des Iand-und Forst- \\ wirtschafts ministerium zu Nishigahara, Tokio, Jajan.)
}

Die Verff. haben einen Übertragungsversuch mit Blutserum anämiekranker, drüsekranker und gesunder Pferde an normalen und milzextirpierten Kaninchen nach dem Verfahren von Oppermann ausgeführt. Die dabei gemachten Erfahrungen lassen sich in folgende Sätze zusammenfassen.

1. Bei den mit dem Blutserum anämiekranker Pferde angesteckten Kaninchen treten die Senkung der Erythrozytenzahl und die Steigerung des Hämoglobinwertes. Ähnliche Veränderungen am Blutbilde werden aber auch bei den mit dem Blutserum drüsekranker oder gesunder Pferde angesteckten Kaninchen beobachtet. Diese Erfahrung zeigt, dass der Kaninchenimpfversuch zur Ermittelung der infelktiösen Anämie nicht streng spezifisch ist.

2. Wenn auch der Kaninchenimpfversuch nach Oppermann als in dem einzelnen Falle mehr oder weniger wertvolles Hilfsmittel angesehen werden kann, so setzt die Notwendigkeit den Wert des Verfahrens in hohem Grade herab, bei dem geimpften Kaninchen die Auszählung der roten Blutkörperchen und die - Bestimmung des Hämoglobingehaltes mindestens 4 wochenlang täglich vorzunehmen.

3. Bei den milzextirpierten und danach mit dem Blutserum anämiekranker Pferde angesteckten Kaninchen wird kein Besonderes bei Veränderungen am Blutbilde beobachtet. 